\title{
Effects of low molecular weight oviductal factors on the development of mouse one-cell embryos in vitro
}

\author{
N. Minami, K. Utsumi and A. Iritani \\ Department of Animal Science, College of Agriculture, Kyoto University, Kyoto 606, Japan
}

\begin{abstract}
Summary. The relationship between the oviduct and embryo development in the mouse was investigated and the period at which the influence of oviduct can be concerned in the development of mouse embryos in vitro was identified. In addition, the relative molecular weight of oviductal factors that promote embryo development was demonstrated. Mouse zygotes developed to the blastocyst stage when co-cultured with ampulla. The period of embryo co-culture significantly affected the further development of the embryos. Fewer one-cell embryos co-cultured with dissected ampullae for less than $24 \mathrm{~h}$ developed to blastocysts than those co-cultured for more than $28 \mathrm{~h}$ $(P<0.001)$. A high percentage of embryos co-cultured with ampullae after $24 \mathrm{~h}$ of culture in vitro developed to the blastocyst stage, which suggests that the influences of ampulla on the development of mouse embryos are restricted to a specific period at the two-cell stage (about 55-56 h after hCG injection) in vitro. Mouse ova that were cultured in media conditioned by ampullae could also develop to the blastocyst stage. The fractionated medium that contained low molecular weight fractions was more effective $(P<0.001)$ on the development of embryos to the blastocyst stage than that containing high molecular weight fractions. These results suggest that the low molecular weight oviductal factors play an important role in the development of mouse embryos at a certain critical age in vitro.
\end{abstract}

Keywords: mouse; embryo development; conditioned medium; oviductal factors

\section{Introduction}

In many mammalian species, the development of one-cell embryos is usually blocked at various early stages in vitro: for example one-cell mouse embryos, with the exception of some inbred strains and $F_{1}$ hybrids of those strains (Whitten \& Biggers, 1968; Kaufman \& Sachs, 1976; Goddard \& Pratt, 1983), exhibit a block at the two-cell stage. Hamster embryos at both the two- and four-cell stages in vitro exhibit similar developmental arrest (Bavister et al., 1983). This failure to cleave beyond the two-cell stage has been termed the 'two-cell block'.

Developmental block, however, is due to the lack of some components in the culture medium (Biggers et al., 1967; Whittingham \& Biggers, 1967; Cross \& Brinster, 1973; Abramczuk et al., 1977; Loutradis et al., 1987) or is caused by an inappropriate environment (Quinn \& Harlow, 1978) for embryo development. For example Whitten's medium containing micromolar concentration of ethylenediaminetetraacetic acid (EDTA) can promote the development of mouse one-cell embryos to the blastocyst stage (Abramczuk et al., 1977). Chatot et al. (1989) reported that a high proportion of one-cell mouse embryos from an outbred strain could develop to the blastocyst stage in vitro in CZB medium. This is a further modification of BMOC-2 medium in which the lactate: pyruvate ratio is changed, glucose is excluded, and glutamine and EDTA are added. Schini \& Bavister (1988) reported that omission of glucose and phosphate from culture medium could provide a better environment for the development of hamster two-cell embryos. Successful 
development of hamster two-cell embryos to blastocysts in HECM-2 was achieved by increased $\mathrm{CO}_{2}$ concentration and by reduced $\mathrm{O}_{2}$ concentration of culture medium (McKiernan \& Bavister, 1990). Muggleton-Harris et al. (1982) and Pratt \& Muggleton-Harris (1988) reported that the block could be overcome by transplantation of cytoplasm from a non-blocked embryo into a blocked embryo, and demonstrated the existence of cell-cycle-related cytoplasmic components.

In vivo, effects of the oviducts on the development of early cleavage stage mouse embryos were demonstrated (Goddard \& Pratt, 1983). Effects of oviducts have been shown in many species by co-culturing embryos with oviductal cells (Gandolfi \& Moor, 1987; Rexroad \& Powell, 1988; Carney et al., 1990; Sakkas \& Trounson, 1990; Ellington et al., 1990) or tissue (Eyestone \& First, 1989; Minami et al., 1991), or by organ culture system (Biggers et al., 1962; Whittingham, 1968; Minami et al., 1988). Although the secretory activity of the oviduct has also been investigated, and some proteins that are secreted have been identified and characterized in mice (Kapur \& Johnson, 1985, 1986), the detailed function for embryo development remains unknown. Development of mouse embryos under the influence of oviduct in vitro can provide a model for the analysis of oviductal factors that promote embryo development.

In this study, experiments were designed to (1) identify the stage at which the embryos could be influenced by the oviductal environment for their development, and (2) examine the effect of conditioned medium fractionated by Sephadex G-25 column on the development of mouse ova in vitro.

\section{Materials and Methods}

\section{Culture medium}

In all experiments, the medium used was modified Whitten's medium (MW) (Hoppe, 1985) containing $5.55 \mathrm{mmol}$ glucose $1^{-1}, 0.27$ mmol sodium pyruvate $1^{-1}$ and $1.62 \mathrm{mmol}$ calcium lactate $1^{-1}$. In Expts 1 and 2 , the medium used for embryo and oviductal tissue culture was MW containing $3 \mathrm{mg}$ bovine serum albumin $\mathrm{ml}^{-1}$ (Armour Pharmaceutical Co., Kankakee, IL, USA) (MW + BSA). In Expts 3, 4 and 5, the media used were MW + BSA and MW containing $4 \mathrm{mg}$ polyvinylpyrrolidone $\mathrm{ml}^{-1}$ (Nacalai Chemical Co., Japan) (MW + PVP). All media used were sterilized by filtration through $0.22 \mu \mathrm{m}$ Millex-GV filters (Millipore Co., Bedford, MA, USA) before use.

\section{Embryo collection}

Five- to seven-week-old randomly bred ICR mice were superovulated with intraperitoneal injections of 5-10 iu pregnant mares' serum gonadotrophin (PMSG; Teikoku Hormone M. F. G. Co. Ltd, Japan) followed $48 \mathrm{~h}$ later by 5-10 iu human chorionic gonadotrophin (hCG; Sankyo Zoki Co., Ltd, Japan). Females were mated overnight with an ICR male on the day of hCG injection. Fertilized one-cell embryos were collected from successfully mated mice at 27-28 h (Expts 1 and 2) or $25 \mathrm{~h}$ (Expts 3-5) after the hCG injection by flushing oviducts with MW + BSA (Expts 1 and 2) or MW + PVP (Expts 3-5).

\section{Preparation of oviductal tissue}

In Expts 1 and 2, oviducts that contained unfertilized eggs were obtained from unmated 5-6-week-old ICR mice superovulated with PMSG and hCG as described above. Oviducts for co-culture were isolated $25 \mathrm{~h}$ after the hCG injection. They were flushed with MW + BSA and transferred to the medium containing three protease inhibitors at final concentrations of $100 \mu \mathrm{mol}$ phenylmethanesulfonyl fluoride $1^{-1}$ (Sigma Chemical Co. Inc., Milwaukee, WI, USA), $10 \mu \mathrm{mol}$ leupeptin $\mathrm{l}^{-1}$ (Sigma Chemical Co.) and $10 \mu \mathrm{mol}$ pepstatin A $1^{-1}$ (Sigma Chemical Co.) (Minami et al., 1991). The isthmic and fimbrial regions of oviducts were removed and the ampullae, opened longitudinally with micro-scissors, were washed with MW + BSA containing the protease inhibitors for about $1 \mathrm{~h}$ to prevent the action of proteases that may have been released from oviductal cells that had been broken during dissection.

\section{Co-culture conditions}

After treatment with protease inhibitors the oviductal tissues were washed several times with MW + BSA (Expts 1 and 2) or MW + PVP (Expts 3-5). They were then carefully cleaned with sterilized filter paper to remove blood and protease inhibitors, and placed on the bottom of $35 \times 10 \mathrm{~mm}$ plastic culture dishes (Nunc, Roskilde, Denmark). In 
Expts 1 and 2,100 $\mu \mathrm{l}$ of MW + BSA was added to each tissue to make a small co-culture drop, and then covered with paraffin oil and equilibrated for at least $1 \mathrm{~h}$ in a humidified gas phase of $5 \% \mathrm{CO}_{2}$ in air at $37^{\circ} \mathrm{C}$ before culture of embryos. Five to fifteen one-cell embryos (identified by the existence of two polar bodies) were added to each co-culture drop.

\section{Conditioning of media}

In Expt 3, five dissected ampullae were placed on the bottom of $35 \times 10 \mathrm{~mm}$ plastic culture dishes, and then $0.5 \mathrm{~m} 1$ of MW + BSA or MW + PVP was added to each dish. These media containing ten dissected ampullae were cultured for 12 or $24 \mathrm{~h}$ in a humidified gas phase, $5 \% \mathrm{CO}_{2}$ in air, at $37^{\circ} \mathrm{C}$ under paraffin oil. In Expts 4 and 5 , the medium used for conditioning was MW + PVP. Twenty dissected ampullae were cultured for $24 \mathrm{~h}$ under the same conditions without paraffin oil. After conditioning, the media were recovered and filter-sterilized before making culture drops in each experiment.

\section{Fractionation of conditioned medium}

The conditioned medium was fractionated on a Sephadex G-25 column (PD-10; Pharmacia, Uppsala, Sweden). After equilibration with $25 \mathrm{ml} \mathrm{MW}+\mathrm{PVP}, 2.5 \mathrm{ml}$ of conditioned medium was placed on top of the column. The high molecular weight fractions were recovered when the column was first eluted with $3.5 \mathrm{ml} \mathrm{MW}+$ PVP. The low molecular weight fractions were collected with the next $5 \mathrm{ml}$ of elution medium. As a result of fractionation of conditioned medium, the high molecular weight fractions were diluted 1-4-times and the low molecular weight fractions were diluted twice. Each eluted medium containing high or low molecular weight fraction was sterilized with $0 \cdot 22 \mu \mathrm{m}$ Millex GV filters, and then used for embryo culture.

\section{Experimental studies}

Experiment 1. The effects of the co-culture period on the development of one-cell embryos were examined. Onecell embryos recovered at $27-28 \mathrm{~h}$ after hCG were placed into $100 \mu \mathrm{l}$ of co-culture medium containing one dissected ampulla. After 12, 16, 20,24, 28, 32 and $36 \mathrm{~h}$ in co-culture, the embryos were transferred to fresh MW + BSA and were examined to determine morphological stages of development. The number and proportion of embryos that reached the four-cell stage after $24,20,16,12,8,4$ and $0 \mathrm{~h}$ in culture, respectively, were recorded. After additional culture for $48 \mathrm{~h}$, the numbers and percentages of blastocysts were also recorded. As a control, embryos were cultured in MW + BSA for $84 \mathrm{~h}$.

Experiment 2. The effects of the starting point and the duration of co-culture were examined. One-cell embryos recovered at 27-28 h after hCG were cultured in vitro for $12,16,20,24$ and $28 \mathrm{~h}$ in MW + BSA, and then co-cultured for $24,20,16,12$ and $8 \mathrm{~h}$ in $\mathrm{MW}+\mathrm{BSA}$ containing one dissected ampulla, respectively. After co-culture, embryos were evaluated and then transferred to fresh MW + BSA. After a further $48 \mathrm{~h}$ of culture, the number of embryos developing to blastocysts was recorded. As control, embryos were cultured in MW + BSA for $84 \mathrm{~h}$.

Experiment 3. The effects of conditioned medium on the development of mouse embryos and supplementation of BSA before conditioning were examined. The embryos were recovered from superovulated mice $25 \mathrm{~h}$ after hCG, by flushing oviducts with MW + PVP, and then cultured in MW + PVP. The oviducts that had contained the embryos were dissected and used to prepare conditioned media. The media used for conditioning were MW + BSA or MW + PVP. After 12 or $24 \mathrm{~h}$ of conditioning, the media were recovered and filtered through $0.22 \mu \mathrm{m}$ Millex GV filter and were used to make $100 \mu \mathrm{l}$ of culture drops. The embryos were cultured in MW + PVP for 14 or $26 \mathrm{~h}$ before transfer to conditioned media and culture for a further 24 or $12 \mathrm{~h}$, respectively. After culture in conditioned media, the embryos were transferred to fresh MW + BSA and cultured for $48 \mathrm{~h}$. The stages of development reached at the end of final culture were recorded.

As control, embryos were cultured throughout in MW + BSA for $86 \mathrm{~h}$.

Experiment 4. The effect of dilution of conditioned medium was examined. MW + PVP were used to prepare the conditioned medium. The conditioning period and culture period in conditioned media were fixed at 24 and $12 \mathrm{~h}$, respectively, in accordance with the result of Expt 3. The conditioned media recovered were diluted two, four or eight times with MW + PVP. As described in Expt 3, the embryos were recovered $25 \mathrm{~h}$ after hCG and cultured in MW + PVP for $26 \mathrm{~h}$, and then transferred to each diluted medium. After $12 \mathrm{~h}$ of culture in each diluted conditioned medium, the embryos were recovered and transferred to fresh MW + BSA. The numbers and percentages of blastocysts were recorded after additional culture for $48 \mathrm{~h}$.

As control, embryos were cultured in MW + PVP for $26 \mathrm{~h}$, and then cultured for $60 \mathrm{~h}$ in fresh MW + BSA.

Experiment 5. The effects of separated fractions of conditioned medium on the development of mouse embryos was examined. As described above, MW + PVP was conditioned for $24 \mathrm{~h}$. After conditioning, the medium that was 
recovered and filtered was separated into two phases by a Sephadex G-25 column. Each separated phase contains low molecular weight fractions or high molecular weight fractions, respectively. After fractionation, $100 \mu$ l culture drops were made from the aliquots of medium containing low or high molecular weight fractions. The embryos were recovered $25 \mathrm{~h}$ after hCG and cultured in MW + PVP for $26 \mathrm{~h}$, and then transferred to each fractionated medium to assess the biological activity of each separated medium. After $12 \mathrm{~h}$ of culture in fractionated media, embryos were transferred to fresh MW + BSA and cultured for $48 \mathrm{~h}$. The number of embryos developing to blastocysts was recorded after additional culture in $\mathrm{MW}+\mathrm{BSA}$.

As control, embryos were cultured in MW + PVP for $26 \mathrm{~h}$, and then cultured in fresh MW + BSA for $60 \mathrm{~h}$.

Duration of culture. The total period of embryo culture in vitro including the co-culture period was $84 \mathrm{~h}$ (Expts 1 and 2) or $86 \mathrm{~h}$ (Expts 3-5). In all experiments, embryos from each female were pooled and assigned randomly among all the treatments within one replicate of the experiment.

\section{Statistical analysis}

In all experiments, data obtained from at least four replicates were combined and expressed as $0-1$ variables and analysed by weighted least squares analysis of variance using the general linear models procedure of the statistical analysis system (SAS Institute, Cary, NC). $P<0.05$ was considered statistically significant.

\section{Results}

\section{Experiment 1}

There were no significant differences in the proportion of blastocysts that developed from onecell embryos (27-28 $\mathrm{h}$ after hCG) co-cultured with ampullae for 12,16 and $20 \mathrm{~h}$; the blastulation rates were $13 \%, 10 \%$ and $16 \%$, respectively (Table 1 ). As the co-culture period was prolonged to more than $24 \mathrm{~h}$, significantly greater proportions of embryos developed into blastocysts. The blastulation rates of embryos co-cultured for $24,28,32$ and $36 \mathrm{~h}$ were $27 \%, 70 \%, 83 \%$ and $82 \%$, respectively. The percentages of four-cell embryos that developed for longer periods (more than $28 \mathrm{~h}$ ) of co-culture were significantly higher than those developed for shorter periods ( $24 \mathrm{~h}$ or less) of co-culture. These results indicated that the ampullae could provide a good environment for mouse one-cell embryos to develop to the blastocyst stage at about 24 to $28 \mathrm{~h}$ in co-culture.

Table 1. Effects of co-culture periods of mouse one-cell embryos with oviductal tissue on their further development in culture

\begin{tabular}{|c|c|c|c|c|c|c|c|}
\hline \multirow{2}{*}{$\begin{array}{l}\text { Co-culture } \\
\text { periods } \\
\text { (h) }\end{array}$} & \multirow{2}{*}{$\begin{array}{c}\text { Number } \\
\text { of } \\
\text { trials }\end{array}$} & \multirow{2}{*}{$\begin{array}{l}\text { Number of } \\
\text { embryos } \\
\text { cultured }\end{array}$} & \multicolumn{3}{|c|}{$\begin{array}{c}\text { Number of embryos } \\
\text { developed by } \\
\text { co-culture* }\end{array}$} & \multicolumn{2}{|c|}{$\begin{array}{c}\text { Number }(\%) \dagger \text { of embryos } \\
\text { developed after } \\
\text { subsequent culture }\end{array}$} \\
\hline & & & $2-$ & $3-$ & 4-cell & 4-cell+ & blastocyst \\
\hline Control & 4 & 71 & 68 & & & $38(54)$ & $10(14)^{b}$ \\
\hline 12 & 4 & 68 & 64 & & & $40(59)$ & $9(13)^{b}$ \\
\hline 16 & 4 & 72 & 72 & & & $45(63)$ & $7(10)^{b}$ \\
\hline 20 & 4 & 69 & 69 & & & $50(72)$ & $1 \rrbracket(16)^{\mathbf{b}, \mathrm{c}}$ \\
\hline 24 & 4 & 74 & 69 & 2 & 2 & $49(66)$ & $20(27)^{\mathrm{c}}$ \\
\hline 28 & 4 & 77 & 20 & 11 & 44 & $73(95)^{a}$ & $54(70)^{d}$ \\
\hline 32 & 4 & 78 & 3 & 3 & 72 & $76(97)^{a}$ & $65(83)^{c}$ \\
\hline 36 & 4 & 83 & 6 & 2 & 72 & $72(87)^{a}$ & $68(82)^{e}$ \\
\hline
\end{tabular}

*Morphological stages of embryos were examined at the end of co-culture.

$\dagger$ All percentages derived from the total number of embryos cultured.

$\$$ All embryos were examined $36 \mathrm{~h}$ after collection.

${ }^{a}$ Significantly different from values without a superscript $(P<0.01)$.

${ }^{\text {bcde }}$ Values with different superscripts are significantly different (be,de $P<0.05$, be,cd,ce $P<0.001$ ). 


\section{Experiment 2}

In this experiment, embryos that had reached the two-cell stage after 12 to $28 \mathrm{~h}$ of culture without ampullae were co-cultured for $24,20,16,12$ and $8 \mathrm{~h}$, respectively. The proportion of blastocysts that developed after co-culture for each of these periods was not significantly different, but all were significantly different from the control (Table 2).

Table 2. Effects of starting time and periods of co-culture on the further development of mouse embryos in vitro

\begin{tabular}{|c|c|c|c|c|c|c|c|}
\hline \multirow{2}{*}{$\begin{array}{l}\text { Start of } \\
\text { co-culture } \\
\text { after collection }\end{array}$} & \multirow{2}{*}{$\begin{array}{l}\text { Co-culture } \\
\text { periods } \\
\text { (h) }\end{array}$} & \multirow{2}{*}{$\begin{array}{c}\text { Number } \\
\text { of } \\
\text { trials }\end{array}$} & \multirow{2}{*}{$\begin{array}{l}\text { Number of } \\
\text { embryos } \\
\text { cultured }\end{array}$} & \multicolumn{3}{|c|}{$\begin{array}{l}\text { Number of } \\
\text { embryos developed } \\
\text { after co-culture } \dagger\end{array}$} & \multirow{2}{*}{$\begin{array}{c}\text { Number }(\%)^{*} \text { of } \\
\text { blastocysts } \\
\text { developed after } \\
\text { subsequent culture }\end{array}$} \\
\hline & & & & 2-, & $3-$, & 4-cell & \\
\hline 12 & 24 & 4 & 50 & 1 & & 49 & $44(88)$ \\
\hline 16 & 20 & 4 & 43 & 2 & 2 & 39 & $37(86)$ \\
\hline 20 & 16 & 4 & 42 & 2 & & 40 & $36(86)$ \\
\hline 24 & 12 & 4 & 48 & 1 & & 47 & $41(85)$ \\
\hline 28 & 8 & 4 & 50 & 1 & 1 & 48 & $38(76)$ \\
\hline Control & 0 & 4 & 54 & 15 & 5 & 34 & $9(17)^{\mathrm{a}}$ \\
\hline
\end{tabular}

*All percentages derived from the total number of embryos cultured.

†All embryos were examined and transferred to medium without co-culture at $36 \mathrm{~h}$ after collection, which was the combined period of incubation before co-culture plus co-culture.

aSignificantly different within same column $(P<0.001)$.

In Expts 1 and 2, most of the four-cell embryos that developed in culture alone or developed in inappropriate co-culture (which does not include the period of about $28 \mathrm{~h}$ after the start of coculture) were morphologically different from those obtained by appropriate co-culture (which includes the period of about $28 \mathrm{~h}$ after the start of co-culture). Four-cell embryos that developed in appropriate periods of co-culture have slightly flattened blastomeres (Fig. 1a). Those that developed in culture without ampullae or in inappropriate co-culture have completely spherical blastomeres (Fig. Ib). The flattened four-cell embryos could develop normally into blastocysts (Fig. 1c), but four-cell embryos having spherical blastomeres did not. Almost all four-cell embryos with spherical blastomeres degenerated when they were cultured for more than $48 \mathrm{~h}$.

\section{Experiment 3}

The embryos cultured in conditioned medium supplemented with BSA or PVP could develop to the blastocyst stage (Table 3). However, there were no significant differences between the conditioned media supplemented with BSA or PVP on the development of embryos to the blastocyst stage even when the conditioned period was either $12 \mathrm{~h}$ or $24 \mathrm{~h}(65 \%$ versus $58 \%, 75 \%$ versus $78 \%$ ). The percentage of blastocysts that developed in $12 \mathrm{~h}$ of culture was significantly lower than that developed in $24 \mathrm{~h}$ of culture when PVP was supplemented before conditioning (58\% versus $78 \%)$.

\section{Experiment 4}

The blastulation rates were significantly reduced when the conditioned medium was diluted. The results indicate that the proportion of blastocysts that developed after subsequent culture gradually decreased as the conditioned media were diluted stepwise (Table 4). 

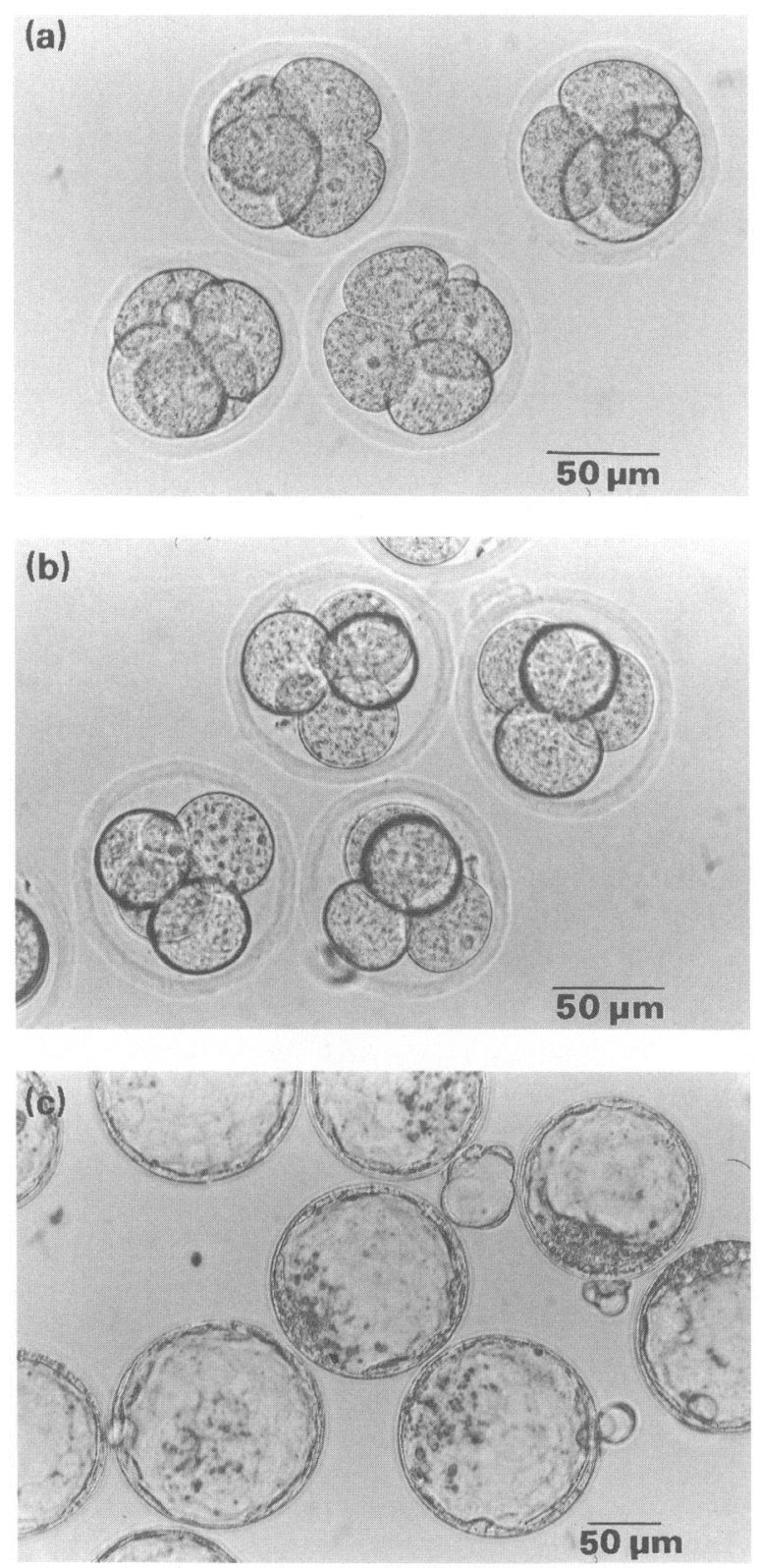

Fig. 1. Embryos developed in culture and in co-culture. (a) Four-cell embryos with flattened blastomeres developed in co-culture for $24 \mathrm{~h}$ and (b) four-cell embryos with spherical blastomeres developed in culture without oviductal tissue. The embryos were photographed at about $40 \mathrm{~h}$ after collection. (c) Blastocysts obtained in the co-culture system.

\section{Experiment 5}

The conditioned medium supplemented with PVP before conditioning was separated into two phases by Sephadex G-25. As shown in Table 5, the conditioned medium that contained low molecular weight fractions had a much greater effect than that containing high molecular weight fractions on the blastulation rate of mouse embryos in vitro $(47 \%$ versus $15 \%)$. In the process of 
Table 3. Effects of the culture medium conditioned by dissected ampullae on the development of mouse embryos in vitro

\begin{tabular}{lcccc}
\hline $\begin{array}{l}\text { Conditioned } \\
\text { periods } \\
\text { (h) }\end{array}$ & $\begin{array}{c}\text { With (+) or } \\
\text { without (-) } \\
\text { BSA }\end{array}$ & $\begin{array}{c}\text { Culture periods } \\
\text { in conditioned } \\
\text { medium } \\
\text { (h) }\end{array}$ & $\begin{array}{c}\text { Number of } \\
\text { embryos } \\
\text { cultured }\end{array}$ & $\begin{array}{c}\text { Number (\%) } \\
\text { of blastocysts } \\
\text { developed after } \\
\text { subsequent culture }\end{array}$ \\
\hline 12 & + & 24 & 54 & $35(65)^{\mathrm{a} . \mathrm{b}}$ \\
& - & 24 & 53 & $31(58)^{\mathrm{a}}$ \\
& + & 12 & 64 & $48(75)^{\mathrm{b}}$ \\
Control & - & 12 & 64 & $50(78)^{\mathrm{b}}$ \\
\hline
\end{tabular}

${ }^{\mathrm{abc}}$ Values with different superscripts are significantly different $(P<0.05)$.

Table 4. Effects of conditioned medium diluted by modified Whitten's medium on the development of mouse embryos

\begin{tabular}{|c|c|c|c|}
\hline $\begin{array}{l}\text { Dilution of } \\
\text { conditioned } \\
\text { medium }\end{array}$ & $\begin{array}{l}\text { Number of } \\
\text { trials }\end{array}$ & $\begin{array}{l}\text { Number of } \\
\text { embryos } \\
\text { cultured }\end{array}$ & $\begin{array}{c}\text { Number }(\%) \\
\text { of blastocysts } \\
\text { developed after } \\
\text { subsequent culture }\end{array}$ \\
\hline 1 & 5 & 52 & $45(83)^{\mathrm{a}}$ \\
\hline $1 / 2$ & 5 & 54 & $34(63)^{b}$ \\
\hline $\mathrm{I} / 4$ & 5 & 53 & $23(43)^{c}$ \\
\hline $1 / 8$ & 5 & 48 & $14(29)^{\mathrm{c}, \mathrm{d}}$ \\
\hline Control & 5 & 48 & $9(19)^{d}$ \\
\hline
\end{tabular}

fractionation of conditioned medium, the low molecular weight fractions were diluted twice, so the percentage of blastocysts obtained in this experiment $(47 \%)$ should be compared with those in Table 4. In Expt 4, the blastulation rate was $63 \%$ when the embryos were cultured in conditioned medium diluted twice.

Table 5. Effects of fractionated media on the development of mouse embryos

\begin{tabular}{lccc}
\hline $\begin{array}{l}\text { Separated } \\
\text { media }\end{array}$ & $\begin{array}{c}\text { Number of } \\
\text { trials }\end{array}$ & $\begin{array}{c}\text { Number of } \\
\text { embryos } \\
\text { cultured }\end{array}$ & $\begin{array}{c}\text { Number (\%) } \\
\text { of blastocysts } \\
\text { developed after } \\
\text { subsequent culture }\end{array}$ \\
\hline $\begin{array}{l}\text { High molecular weight } \\
\text { fraction }\end{array}$ & 4 & 94 & $14(15)$ \\
$\begin{array}{l}\text { Low molecular weight } \\
\text { fraction }\end{array}$ & 4 & 98 & $46(47)^{\mathrm{a}}$ \\
Control & 4 & 92 & $16(17)$ \\
\hline
\end{tabular}

${ }^{a}$ Significantly different within same column $(P<0.001)$.

The high molecular weight fraction was diluted 1.4 times and the low molecular weight fraction was diluted twice. 


\section{Discussion}

In the present study, we demonstrated the time at which mouse embryos are influenced by the ampulla for their further development and the possibility that the low molecular weight fractions that originate in the ampullae can promote the development of mouse embryos to the blastocyst stage in vitro.

Development of mouse one-cell embryos to blastocysts was significantly promoted by coculture with dissected ampullae for $24,28,32$ and $36 \mathrm{~h}(27 \%, 70 \%, 83 \%$ and $82 \%)$, but the percentage of blastocysts that developed in $24 \mathrm{~h}$ of co-culture was significantly lower $(P<0.001)$ than the percentage of those developed in co-culture for 28,32 and $36 \mathrm{~h}$ (Table 1). In contrast, the blastulation rates of one-cell embryos co-cultured with dissected ampullae for $24 \mathrm{~h}$ or less were as low as that of embryos cultured without ampullae (Table 1). The percentages of four-cell embryos that developed during longer periods (more than $28 \mathrm{~h}$ ) of co-culture were also significantly higher than those developed in shorter periods ( $24 \mathrm{~h}$ or less) of co-culture (Table 1). These results suggest that oviductal influences are not sufficient for the development of embryos to blastocysts until $24 \mathrm{~h}$ after collection (51-52 h after hCG), and also suggest that embryos co-cultured with ampullae acquire some factors from the oviduct at about $28 \mathrm{~h}$ of co-culture in this system. This possibility was confirmed by culturing one-cell embryos in MW + BSA for 12, 16, 20, 24 and $28 \mathrm{~h}$, and then co-culturing for $24,20,16,12$ and $8 \mathrm{~h}$, respectively. There was no effect of the time of beginning co-culture or duration of co-culture. These results showed that the absence of oviductal influence for the first $28 \mathrm{~h}$ after collection did not affect embryo development to blastocysts in vitro. Most embryos that had reached beyond the two-cell stage after co-culture for more than $28 \mathrm{~h}$ could develop to blastocysts after subsequent culture, but more critical effects of oviduct for embryo development were observed when co-culture periods were prolonged for more than $32 \mathrm{~h}$ (Table 1). This suggests that embryos are influenced by the oviducts between the late two-cell stage and just before the four-cell stage to develop further beyond the four-cell stage to the blastocyst stage; in other words, this stimulation from the oviduct becomes evident about $28 \mathrm{~h}$ after embryo collection. This period coincides with the G2 phase of the second cell cycle (Fig. 2) (Luthardt \& Donahue, 1975; Bolton et al., 1984), the timing of the switch from maternal to embryonic genomic control (Braude et al., 1979; Flach et al., 1982; Bolton et al., 1984). Thus, the factor(s) that activates the next cell cycle may be required for the embryos at about $28 \mathrm{~h}$ after collection $(55-56 \mathrm{~h}$ after hCG, Fig. 2). This factor may be produced by the ampullar region of oviduct, but the embryos are not sensitive to this factor until they reach a certain developmental stage. To examine the existence of oviductal factor(s) that promote(s) the development of embryos, we used the media conditioned by ampullae for embryo culture. Development of one-cell embryos cultured in conditioned media to blastocysts was significantly enhanced, even though the supplemented BSA was replaced by PVP $(75 \%$ and $78 \%)$. From these results, it is demonstrated that the analysis of oviductal factors is possible without the influence of exogenous proteins.

Other investigators have demonstrated the existence of oviduct-specific glycoproteins in mice (Kapur \& Johnson, 1985, 1986), hamsters (Robitaille et al., 1988), rabbits (Shapiro et al., 1974), sheep (Sutton et al., 1984; Gandolfi et al., 1989), baboons (Fazleabas \& Verhage, 1986) and cattle (Boice et al., 1990), but the biological functions of these molecules have not yet been determined. Although high molecular weight fractions had no effect on the development of embryos (Table 5), the proportion of blastocysts that developed under the influence of low molecular weight oviductal factors was not that high (47\%) compared with the result in Table $4(63 \%)$. This may indicate that the interaction between the low and high molecular weight fractions has some effect on the full development of mouse embryos in vitro. Heyman et al. (1987) have reported the involvement of a low molecular weight fraction from trophoblastic vesicles in the development of bovine embryos, and low molecular weight extracts of BSA that stimulate rabbit blastocyst cell division and expansion have also been shown by Kane (1985), but they are not from the oviduct. This study is the first report of the involvement of low molecular weight components in embryo development. In 


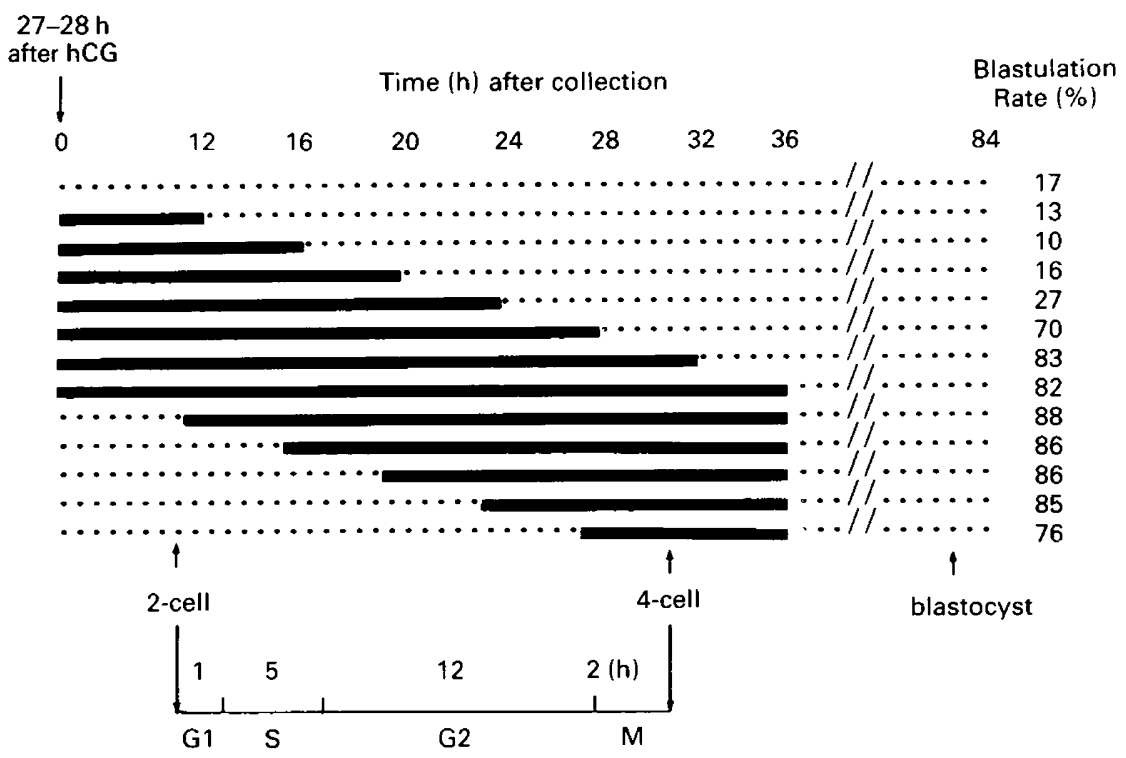

Fig. 2. Second cell cycle of mouse embryos and blastulation rates. Diagram of the relationship between the cell cycle and the blastulation rates of mouse embryos in culture and in co-culture. The total duration of culture of the embryos with or without co-culture is shown. ' 0 ' time on this scale was $27-28 \mathrm{~h}$ after hCG administration. The blastulation rates are taken from the data of Tables 1 and 2. The diagram of the embryonic cell cycle is modified from Luthardt \& Donahue (1975) and Bolton et al. (1984). The dotted lines show the duration of culture of the embryos in medium alone; the solid lines indicate the duration of co-culture.

addition, our preliminary characterization of the active fraction has shown that over $50 \%$ of activity seems to be retained despite heating to $100^{\circ} \mathrm{C}$ for $5 \mathrm{~min}$.

Most of the four-cell embryos developed in co-culture for $24 \mathrm{~h}$ or less failed to develop to blastocysts (Table 1), and, as shown in Fig. la and b, four-cell stage embryos that developed during appropriate periods of co-culture were morphologically different from those obtained after inappropriate periods of co-culture, or from those obtained in culture without ampulla. In Table 1, $57 \%$ ( 44 of 77 ) of embryos were already at the four-cell stage after $28 \mathrm{~h}$ of co-culture, although they should be at the late two-cell stage according to Fig. 2. This indicates that the oviductal factor(s) may be speeding up the cell cycle, but morphological flattening did not occur even when the fourcell embryos with spherical blastomeres were cultured further, and also they could not develop beyond the four-cell stage. From these data, this morphological change in the four-cell stage (Fig. 1a) may be involved in their activity and the developmental fate of these embryos may be determined before they reach the four-cell stage. However, the relationship between the low molecular weight oviductal factors and these morphological differences remains to be determined.

In conclusion, the period during which embryos are influenced by the oviduct for their development is restricted to about $28 \mathrm{~h}$ after collection. Before this period, embryos are apparently not influenced by the oviductal factors that are thought to promote embryo development. These results indicate that low molecular weight fractions play an important role in the development of mouse embryos during a certain critical period at the two-cell stage, and that the function of the oviduct for the embryo development can be analysed.

The low molecular weight oviductal factors described here may be useful in clarifying the biochemical nature of environmental factors necessary for the development of early preimplantation embryos. 
The authors are grateful to B. D. Bavister for reading and commenting on this manuscript, and we thank K. Yanagita for her technical assistance. This work was supported by grants from the Ministry of Education, Science and Culture (No. 01480095 and No. 03207105).

\section{References}

Abramczuk, J., Solter, D. \& Koprowski, H. (1977) The beneficial effect of EDTA on development of mouse one-cell embryos in chemically defined medium. Developmental Biology 61, 378-383.

Bavister, B.D., Leibfried, M. \& Lieberman, G. (1983) Development of preimplantation embryos of golden hamster in a defined culture medium. Biology of Reproduction 28, 235-247.

Biggers, J.D., Gwatkin, R.L.B. \& Brinster, R.L. (1962) Development of mouse embryos in organ culture of Fallopian tubes on a chemically defined medium. Nature 194, 747-749.

Biggers, J.D., Whittingham, D.G. \& Donahue, R.P. (1967) The pattern of energy metabolism in the mouse oocyte and zygote. Proceedings of the National Academy of Sciences USA 58, 560-567.

Boice, M.L., Geisert, R.D., Blair, R.M. \& Verhage, H.G. (1990) Identification and characterization of bovine oviductal glycoproteins synthesized at estrus. Biology of Reproduction 43, 457-465.

Bolton, V.N., Oades, P.J. \& Johnson, M.H. (1984) The relationship between cleavage, DNA replication, and gene expression in the mouse 2-cell embryo. Journal of Embryology and Experimental Morphology 79, 139-163.

Braude, P., Pelham, H., Flach, G. \& Lobatto, R. (1979) Post-transcriptional control in the early mouse embryo. Nature 282, 102-105.

Carney, E.W., Tobback, C., Ellington, J.E. \& Foote, R.H. (1990) Co-culture of rabbit 2-cell embryos with rabbit oviduct epithelial cells and other somatic cells. Molecular Reproduction and Development 27, 209-215.

Chatot, C.L., Ziomek, C.A., Bavister, B.D., Lewis, J.L. \& Torres, I. (1989) An improved culture medium supports development of random-bred 1-cell mouse embryos in vitro. Journal of Reproduction and Fertility 86, 679-688.

Cross, P.C. \& Brinster, R.L. (1973) The sensitivity of one-cell mouse embryos to pyruvate and lactate. Experimental Cell Research 77, 57-62.

Ellington, J.E., Carney, E.W., Farrell, P.B., Simkin, M.E. \& Foote, R.H. (1990) Bovine 1-2-cell embryo development using a simple medium in three oviduct epithelial cell coculture systems. Biology of Reproduction 43, 97-104.

Eyestone, W.H. \& First, N.L. (1989) Co-culture of early cattle embryos to the blastocyst stage with oviducal tissue or in conditioned medium. Journal of Reproduction and Fertility 85, 715-720.

Fazleabas, A.T. \& Verhage, H.G. (1986) The detection of oviduct-specific proteins in the Baboon (Papio anubis). Biology of Reproduction 35, 455-462.

Flach, G., Johnson, M.H., Braude, P.R., Taylor, R.A.S. \& Bolton, V.N. (1982) The transition from maternal to embryonic control in the 2-cell mouse embryo. EMBO Journal 1, 681-686.
Gandolfi, F. \& Moor, R.M. (1987) Stimulation of early embryonic development in the sheep by co-culture with oviduct epithelial cells. Journal of Reproduction and Fertility 81, 23-28.

Gandolfi, F., Brevini, T.A.L., Richardson, L., Brown, C.R. \& Moor, R.M. (1989) Characterization of proteins secreted by sheep oviduct epithelial cells and their function in embryonic development. Development 106, 303-312.

Goddard, J.M. \& Pratt, H.P.M. (1983) Control of events during early cleavage of the mouse embryo: an analysis of the "2-cell Block". Journal of Embryology and Experimental Morphology 73, 111-133.

Heyman, Y., Menezo, Y., Chesne, P., Camous, S. \& Garnier, V. (1987) In vitro cleavage of bovine and ovine early embryos: improved development using coculture with trophoblastic vesicles. Theriogenology 27, 59-68.

Hoppe, P.C. (1985) Technique of fertilization in vitro. In Reproductive Toxicology, pp. 191-199. Ed. R. L. Dixon. Raven Press, New York.

Kane, M.T. (1985) A low molecular weight extract of bovine serum albumin stimulates rabbit blastocyst cell division and expansion in vitro. Journal of Reproduction and Fertility 73, 147-150.

Kapur, R.P. \& Johnson, L.V. (1985) An oviductal fluid glycoprotein associated with ovulated mouse ova and early embryos. Developmental Biology 112, 89-93.

Kapur, R.P. \& Johnson, L.V. (1986) Selective sequestration of an oviductal fluid glycoprotein in the perivitelline space of mouse oocytes and embryos. Journal of Experimental Zoology 238, 249-260.

Kaufman, M.H. \& Sachs, L. (1976) Complete preimplantation development in culture of parthenogenetic mouse embryos. Journal of Embryology and Experimental Morphology 35, 179-190.

Loutradis, D., John, D. \& Kiessling, A.A. (1987) Hypoxanthine causes a 2-cell block in random-bred mouse embryos. Biology of Reproduction 37, 311-316.

Luthardt, F.W. \& Donahue, R.P. (1975) DNA synthesis in developing two-cell mouse embryos. Developmental Biology 44, 210-216.

McKiernan, S.H. \& Bavister, B.D. (1990) Environmental variables influencing in vitro development of hamster 2-cell embryos to the blastocyst stage. Biology of Reproduction 43, 404413.

Minami, N., Bavister, B.D. \& Iritani, A. (1988) Development of hamster two-cell embryos in the isolated mouse oviduct in organ culture system. Gamete Research 19, 235-240.

Minami, N., Utsumi, K. \& Iritani, A. (1991) Oviductal tissue is effective at a certain critical age of mouse embryo. Theriogenology 35, 243 (Abstract).

Muggleton-Harris, A., Whittingham, D.G. \& Wilson, L. (1982) Cytoplasmic control of preimplantation development in vitro in the mouse. Nature 229, 460-462.

Pratt, H.P.M. \& Muggleton-Harris, A.L. (1988) Cycling cytoplasmic factors that promote mitosis in the 
cultured 2-cell mouse embryo. Development 104, $115-120$.

Quinn, P. \& Harlow, G.M. (1978) The effect of oxygen on the development of preimplantation mouse embryos in vitro. Journal of Experimental Zoology 206, 73-80.

Rexroad, C.E. \& Powell, A.M. (1988) Co-culture of ovine ova with oviductal cells in medium 199. Journal of Animal Science 66, 947-953.

Robitaille, G., St-Jacques, S., Potier, M. \& Bleau, G. (1988) Characterization of an oviductal glycoprotein associated with the ovulated hamster oocyte. Biology of Reproduction 38, 687-694.

Sakkas, D. \& Trounson, A.D. (1990) Co-culture of mouse embryos with oviduct and uterine cells prepared from mice at different days of pseudopregnancy. Journal of Reproduction and Fertility 90, 109-118.

Schini, S.A. \& Bavister, B.D. (1988) Two-cell block to development of cultured hamster embryos is caused by phosphate and glucose. Biology of Reproduction 39, 1183-1192.
Shapiro, S.S., Brown, N.E. \& Yard, A.S. (1974) Isolation of an acidic glycoprotein from rabbit oviducal fluid and its association with the egg coating. Journal of Reproduction and Fertility 40, 281-290.

Sutton, R., Nancarrow, C.D., Wallace, A.L.C. \& Rigby, N.W. (1984) Identification of an oestrus-associated glycoprotein in oviducal fluid of sheep. Journal of Reproduction and Fertility 72, 415-422.

Whitten, W.K. \& Biggers, J.D. (1968) Complete development in vitro of the preimplantation stage of the mouse in a simple chemically defined medium. Journal of Reproduction and Fertility 17, 399-401.

Whittingham, D.G. (1968) Development of zygotes in cultured mouse oviducts: I. The effect of varying oviductal conditions. Journal of Experimental Zoology 169, 391-398.

Whittingham, D.G. \& Biggers, J.D. (1967) Fallopian tube and early cleavage in the mouse. Nature 213, 942.

Received 4 November 1991 